
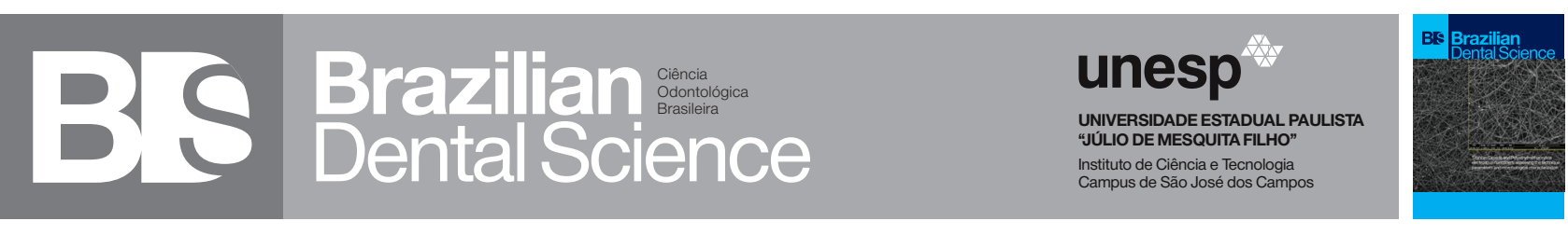

\title{
Proximal retention grooves may increase early fracture strength of ART restorations
}

\author{
Sulcos de retenção proximal podem aumentar a resistência a fratura precoce de restaurações de ART
}

Érica Priscila FERNANDES ${ }^{1}$, Maria Cristina Carvalho de Almendra FREITAS ${ }^{2}$, Paula Vanessa Pedron OLTRAMARI-NAVARRO ${ }^{3}$, Ricardo de Lima NAVARRO ${ }^{3}$, Rafael MENEZES-SILVA ${ }^{1}$, Linda WANG ${ }^{1}$, José Roberto Pereira LAURIS ${ }^{1}$, Maria Fidela de Lima NAVARRO ${ }^{1}$

1 - Department of Dental Materials, Endodontics and Operative Dentistry - Bauru School of Dentistry - University of São Paulo - Bauru SP - Brazil.

2 - Department of Dentistry - Differential Integral College - Teresina - Piauí - Brazil.

3 - Department of Dentistry - University of North Paraná - Londrina - PR - Brazil.

\section{ABSTRACT}

Objective: To evaluate the fracture resistance (RF) of Class II Glass-ionomer Cement (GIC) ART restorations with and without proximal retentions. Material and Methods: 20 freshly extracted human molars were used. Forty (40) standard Mesial-Occlusal (MO) and DistalOcclusal (DO) preparations (20 for each material) were performed with a 245 bur. The unprepared surfaces of the teeth were protected with nail polish and the specimens submerged in 0.5Mol EDTA solution, $\mathrm{pH} 7.4$ for $8 \mathrm{~h}$ under stirring. The preparations were finished with dentine spoons and 50\% received proximal retention with \# 3 excavators. 20 cavities were restored with Chemfil Rock (10 with retention and 10 without retention) and 20 cavities were restored with Equia Fil (10 with retention and 10 with no retention) and were stored in an oven at $37^{\circ} \mathrm{C}$ and $100 \%$ relative humidity for $24 \mathrm{~h}$ and submitted to axial compression loading in Test Machine - EMIC at a rate of $0.5 \mathrm{~mm} /$ minute, until restoration fracture occurred. The values were analyzed by two-way ANOVA $(\mathrm{p}<0.05)$. Results: ChemFil Rock presented 300.84 (69.20) (without retention) and 361.70 (81.08) (with retention) and Equia Fil showed 314.60 (69.97) (without retention) and 366.67 (103.38) (with retention). Data obtained with retention were statistically superior to those obtained with non-retained ART restorations $(p=0.014)$. No statistical differences were detected between materials $(p=0.761)$. Conclusion: Retentive grooves improved fracture resistance of Class II GIC ART restorations.

\section{KEYWORDS}

Dental materials; ART; Glass ionomer cements.

\section{RESUMO}

Objetivo: avaliar a resistência à fratura (FR) de restaurações de ART de Classe II de Cimento de ionômero de vidro (CIV) com e sem retenções proximais. Material e Métodos: Foram utilizados 20 molares humanos recém-extraídos. 40 cavidades padronizadas no sentido Mesial-Oclusal (MO) e Oclusal-Distal (OD) (20 para cada material) foram realizadas com uma broca 245. Os preparos cavitários foram submersos em solução 0,5 mol Mol EDTA, pH 7,4 por 8h sob agitação e foram finalizados com colheres de dentina, nos quais $50 \%$ receberam retenções proximais com escavadores \#3. 20 cavidades foram restauradas com Chemfil Rock (10 com e 10 sem retenção) e 20 cavidades foram restauradas com Equia Fil (10 com e $10 \mathrm{sem}$ retenção) e armazenadas em estufa a $37^{\circ} \mathrm{C}$ e $100 \%$ de umidade relativa por $24 \mathrm{~h}$ e submetidos a carga axial de compressão na máquina de ensaios EMIC a uma taxa de $0,5 \mathrm{~mm} / \mathrm{min}$, até que a fratura de restauração ocorresse. Os valores foram analisados por ANOVA twoway ( $\mathrm{p}<0,05)$. Resultados: ChemFil Rock apresentou 300.84 (69.20) (sem retenção) e 361.70 (81.08) (com retenção) e o Equia Fil apresentou 314.60 (69.97) (sem retenção) e 366.67 (103.38) (com retenção). Os dados obtidos com retenção foram estatisticamente superiores àqueles sem retenção $(\mathrm{p}=0.014)$. Não houve diferença estatística entre os materiais $(\mathrm{p}=0.761)$. Conclusão: Os sulcos retentivos melhoraram a resistência à fratura de restaurações de ART de Classe II de Cimento de ionômero de vidro (CIV).

\section{PALAVRAS-CHAVE}

Materiais dentários; ATR; Cimento de ionômero de vidro. 


\section{INTRODUCTION}

$\mathrm{T}$ is known that Glass-ionomer cements (GICs) 1 have numerous properties that allow their use in large scale in dentistry, among them, adhesion to surface of the natural tooth and fluoride release [1].

In the early-1990s the high viscosity glassionomer cements (HVGICs) appeared, which had improved properties as higher compression resistance compared to medium restorative GICs [2]. The HVGICs has the characteristic of reducing the average particle size and its better distribution within the matrix, allowing an improvement in its properties. In addition, fine grains of glass particles and freezedried polyacrylic acid (7-9\%) were blended into the conventional powder particles. The concentration and molecular weight of the polyacids were also optimized in order to obtain a minimum viscosity for the liquid, which is the basis for high powder / liquid ratio [2].

Beside, the technique of Atraumatic Restorative Treatment (ART) was introduced in the 1980s and is defined as a preventive and minimally invasive dental procedure [3].

Regarding the type of material used, a meta-analysis observed for restorations using the ART technique that, when using high viscosity glass-ionomer cements, the survival rate was higher compared to medium viscosity glass-ionomers [4].

A meta-analysis of the longevity of ART restorations has concluded that survival of single-sided restorations on deciduous and permanent posterior teeth is high, multiple faces in deciduous posterior teeth are low, and that there are small numbers of studies on ART restorations in posterior teeth [5].

More recently, HVGICs were launched that have in their composition changes such as the incorporation of zinc in their composition, ChemFil Rock (Dentsply DeTrey GmbH) [6], and also that have a photoactivated resin coating with nanoparticles, such as Equia Fil (GC Corporation) [7]. These ionomers show a significant increase in flexural strength and compression when compared to high viscosity ionomers such as Ketac Molar Easymix (3M/ ESPE), while the compressive and flexural strengths of Equia Fil (GC Corporation) of are respectively $358.5 \mathrm{MPa}$ and $49.8 \mathrm{MPa}$ and the compressive and flexural strength of ChemFil Rock (3M/ESPE) are $343.1 \mathrm{MPa}$ and $46.5 \mathrm{MPa}$, respectively, Ketac Molar Easymix (3M/ESPE) presents $240.3 \mathrm{MPa}$ and $28.9 \mathrm{MPa}$ of compressive and flexural strength, respectively [8].

Recent studies seek to find new alternatives that may provide greater longevity to multiple surface restorations using GICs in permanent teeth. One of these alternatives was the development of encapsulated HVGICs that allowed an increase in the flexural strength of these materials [8]. Another measure that may increase the longevity of the multiple-face restorations of GICs is the creation of retention niches near the amelodendin junction using a rotating instrument in cases of conventional restorations [9].

There is still a need for laboratory testing, with the preparation of cavities and retentions with manual instruments required by the ART technique.

Therefore, the objective of this study is to test Class II cavity restorations with GICs of highest resistance performed with and without proximal retention grooves.

The null hypothesis are: there is difference between Class II cavity restorations with and without proximal retention grooves; and there is no difference between the materials used.

\section{MATERIALS AND METHODS}

This research project was approved (CAAE: 07980812.8.0000.5417) by the Human Research Ethics Committee of the Bauru School of Dentistry - FOB / USP, created based on Resolution 196/96 of the Ministry of Health.

\section{Sample}

Newly extracted and donated human 
permanent molar teeth indicated for extraction were used for research. The teeth were cleaned and stored in saline solution with $0.1 \%$ thymol $[9,10]$.

Of these, 20 teeth were selected free of caries and cracks or fractures. Their occlusal surface was removed about $1.5 \mathrm{~mm}$ below the cusp tips with water-cooled disk, so that the occlusal surface was flat, and the occlusal fissure remained intact. The proximal faces were also cut about $1.0 \mathrm{~mm}$ with water-cooled disk so that they were flat [9]. The planning of these faces aimed at the standardization of cavities and restorations. Half of the apical portion of the root of the tooth was also sectioned, and the specimens were included in resin up to $1.0 \mathrm{~mm}$ below the enamel dentin junction in a polyvinyl chloride ring, $21 \mathrm{~mm}$ in diameter by $20 \mathrm{~mm}$ in height [9]. The teeth were held in a parallelogram while the resin was being clamped to ensure parallelism of the occlusal surface and the base of the cylinder [9].

\section{Preparation of specimens}

The operator trained with the two materials for this particular study to be able to produce calibrated restorations and trained in mechanical testing and not involved in the procedures aforementioned carried out all the fracture resistance tests.

Forty standard Mesial-Occlusal (MO) and Distal-Occlusal (DO) (20 of each) preparations were initially performed with \# 245 carbide bur (KG Sorensen, São Paulo, SP, Brazil), with at high speed under copious water cooling, in a device adapted from the platform of a microscope [9].

The unprepared surfaces of the tooth were protected with nail polish and the specimens submerged in $40 \mathrm{~mL}$ of $0.5 \mathrm{~mol} / \mathrm{L}$ EDTA solution, $\mathrm{pH} 7.4$ where they remained for 8 hours under agitation for demineralization, simulating a carious cavity [9].

The specimens were numbered from 1 to 20 and the Mesial or Distal faces were drawn to be finalized with dentine spoons (Figure 1). The test group received additional retentions in the proximal boxes with excavators \# 3 of the ART kit (SS White-Duflex Dental Articles Ltda, Rio de Janeiro, RJ, Brazil). The retentive grooves were located $0.5 \mathrm{~mm}$ from the enamel dentin junction and extended in the gingival-occlusal direction up to $0.5 \mathrm{~mm}$ short of the enamel dentin junction in occlusal (Figure 2). The tooth itself housed the test and control groups. Thus, if the mesial face was drawn to harbor the cavity with additional retentions, the distal face harbored the cavity that was finished with dentin spoon excavator of the ART set (SS White-Duflex Dental Articles Ltda, Rio de Janeiro, RJ, Brazil) without additional retentions in the proximal box. First, the types of preparation (with and without retention) were randomized chosen, and after, the restorative material. The final measurements of the cavities in the occlusal box were: $1.5 \mathrm{~mm}$ deep, $3.0 \mathrm{~mm}$ wide and $3.0 \mathrm{~mm}$ in the MD direction; In the proximal box were: $3.0 \mathrm{~mm}$ high, $3.0 \mathrm{~mm}$ wide and $1.5 \mathrm{~mm}$ deep (Figure 3).

After completion of the cavities, the teeth were divided into two groups of 10 teeth each, which were restored with the two materials being tested.

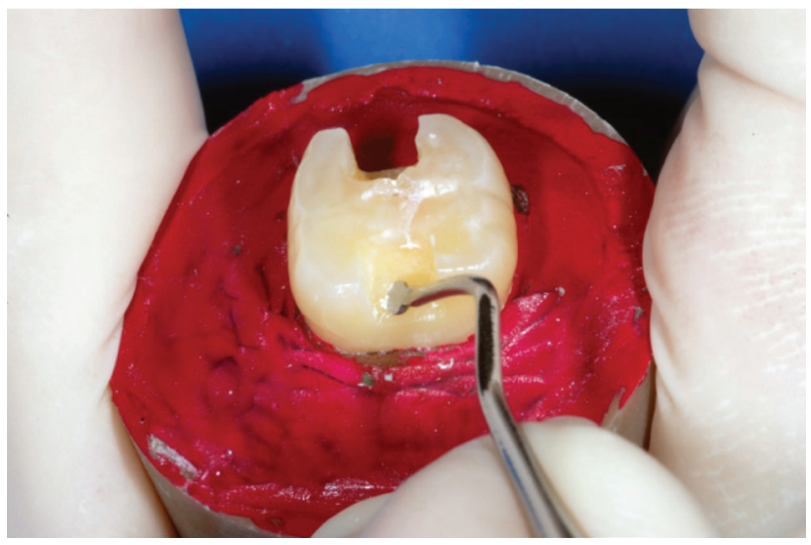

Figure 1- Spoon excavator preparing the ART cavity. 


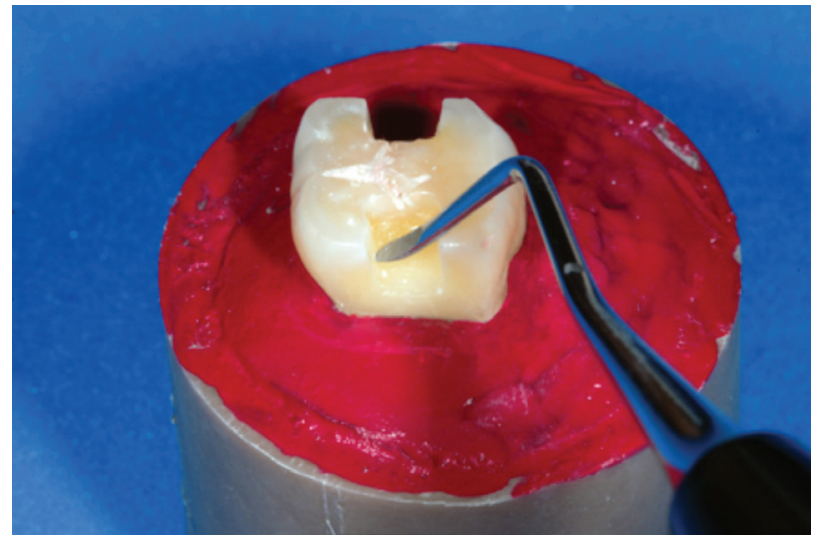

Figure 2 - Retentive groove being prepared by excavators \# 3 of the ART kit.
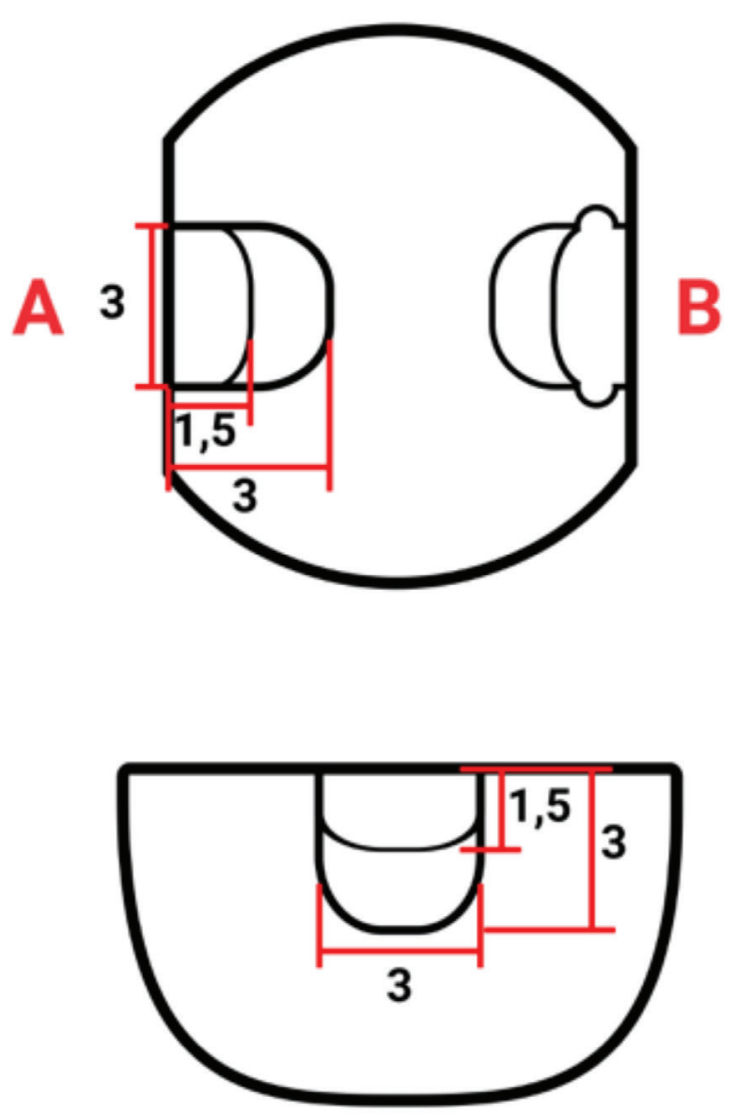

C

Figure 3 - Schematic occlusal (A and B) and proximal (C) views of the cavities: $1.5 \mathrm{~mm}$ deep, $3.0 \mathrm{~mm}$ wide and $3.0 \mathrm{~mm}$ in the MD direction.

\section{Restoration}

The restorations were performed in an environment with a temperature of $23 \pm 1^{\circ} \mathrm{C}$ and relative air humidity of $50 \pm 10 \%$, as recommended by ADA specification \#66 [11].

The teeth were restored with two types of glass ionomer. The trade name, abbreviations and batch number of the materials are given in Table 1.

Manufacturers do not recommend acid conditioning of cavity walls for ChemFil Rock. For the Equia Fil it is recommended the conditioning of the cavity walls with $20 \%$ polyacrylic acid (GC Cavity Conditioner) for 10s.

Table 1 - Products used, characteristics, respective manufacturers and abbreviations

\begin{tabular}{|c|c|c|c|}
\hline MATERIALS & BATCH\# & $\begin{array}{l}\text { MANUFAC- } \\
\text { TURER }\end{array}$ & ABBREVIATION \\
\hline ChemFil Rock & 1110002335 & Dentsply & CR \\
\hline Equia Fil & 1212209 & GC Corporation & $E Q$ \\
\hline
\end{tabular}

The cavities were cleaned with cotton balls soaked in water and then dried with cotton balls. The teeth to be restored with EQ had their cavities cleaned by applying the Cavity Conditioner for 10s, followed by the application of cotton balls soaked in water and dried with cotton balls. This procedure was repeated twice. $\mathrm{T}$ - shaped matrices (Jon - Comércio de Produtos Odontológicos

Ltda, São Paulo, SP, Brazil) were tightly fitted around the teeth, covering the gingival margin of the preparation and standing at the level of the occlusal plane.

\section{Restoration with Equia Fil}

The capsule was removed from the carton only at the time of use. The encapsulated material was activated according to the manufacturer's instructions. The capsule was shaken to loosen powder; the plunger was then pressed into the capsule and placed into GC capsule applier, being compressed to the first click. Immediately after, set into an Astronmix mixer (Dabi Atlante 
Ind. Médico Odontológicas, Ribeirão Preto, SP, Brazil) with 4200 oscillations per minute for 10 seconds. Then, immediately the mixed capsule was removed from the mixer and load into the GC capsule applier and pressed the plunger until the two clicks and the material was ejected. Carefully GIC was injected into the cavity, starting from the deepest part of the cavity and with drawing with slight excess.

Immediately after the insertion of the GIC a glass slide (Microblanding Tebori, Caxias do Sul, RS, Brazil) covered with a thin layer of petroleum jelly (Rioquímica, São José do Rio preto, SP, Brazil) was placed on the occlusal surface of the restoration and the restorative material was compressed with the index finger for $1 \mathrm{~min}$.

\section{Restoration with ChemFil Rock}

The capsule was removed from the carton only at the time of use. The plunger was introduced into the capsule by pressing the capsule onto a stable surface and depressing the plunger to its limit and then taken to an Astronmix mixer (Dabi Atlante Ind. Medico Odontológicas, Ribeirão Preto, SP, Brazil) with 4200 oscillations per minute for $15 \mathrm{~s}$. Immediately thereafter, it was taken into the Capsule Extruder, the trigger of the Capsule Extruder was clicked twice and when the glass-ionomer paste was seen through the tip of the capsule, the material was started dispensing at the deepest part of the cavity and with drawing tip carefully until the cavity was filled with slight excess. Immediately after the insertion of the GIC a glass slide (Microblanding Tebori, Caxias do Sul, RS, Brazil) covered with a thin layer of petroleum jelly (Rioquímica, São José do Rio preto, SP, Brazil) was placed on the occlusal surface of the restoration and the restorative material was compressed with the index finger for $1 \mathrm{~min}$.

For both materials, the glass slide remained for 6 minutes, and then any excesses were removed with a scalpel blade (LAMEDID, Guarulhos, SP, Brazil) and the matrix was carefully removed. Specimens were stored in $100 \%$ relative humidity for $24 \mathrm{~h}$ in an incubator (Fanen, São Paulo, SP, Brazil) at $37^{\circ} \mathrm{C}$.

\section{Fracture resistance}

Immediately before the test, a $0.5 \mathrm{~mm}$ depression was made with a \#4 round bur (Kg Sorensen, São Paulo, SP, Brazil), at low speed, equidistant from the Buccal (B) and Lingual (L) margins of the restoration and $1.5 \mathrm{~mm}$ in the $\mathrm{MD}$ direction, in relation to the proximal limit of the restoration. The axial compression loading tests were performed in a Testing Machine (EMIC, São José dos Pinhais, PR, Brazil) coupled to a computer. This machine was calibrated in the working scale of $100 \mathrm{Kg}$, with load cell of $500 \mathrm{Kg}$ and speed of $0.5 \mathrm{~mm} / \mathrm{min}$. The application of the axial loading force was transmitted to the tooth by means of a device, coupled to the load cell, in the form of a cylinder with a diameter of $8 \mathrm{~mm}$ and a spheroidal active tip with a diameter of $1.5 \mathrm{~mm}$. The active tip transmitted the compression force to the restoration, parallel to the long axis of the tooth until fracture of the restoration occurred [9].

\section{Statistical analysis}

The values obtained in Kgf were analyzed by two-way (material and retention) ANOVA at $5 \%(\mathrm{p}<0.05)$ significance level.

\section{RESULTS}

The means and standard deviations of the values of fracture resistance were registered in Kgf and are shown in table 2.

Table 2 - Mean and standard deviations of ART Class II restorations with and without proximal retentions (Kgf)

\begin{tabular}{|ccc|}
\hline Restorative Material & Without retention & With retention \\
\hline ChemFil Rock & $300.84(69.20) \mathrm{A}$ & $361.70(81.08) \mathrm{B}$ \\
\hline Equia Fil & $314.60(69.97) \mathrm{A}$ & $366.67(103.38) \mathrm{B}$ \\
\hline
\end{tabular}

The results designated with the same letter are not statistically different $(p<0.05)$.

A statistical significance was observed when retentive grooves were made for both materials $(p=0.014)$. No statistical differences were detected between materials $(p=0.761)$. Thus, the hypothesis was accepted. 


\section{DISCUSSION}

The fracture strength of Class II restorations with glass ionomer cements of improved mechanical properties was statistically superior when proximal retentions were performed. This superior performance was observed for both materials being tested.

In order to avoid interference of different degree of mineralization among the teeth tested, two preparations were performed and the same tooth.

The use of the encapsulated glass ionomer, while determining a higher final price for the product, allows perfect control of the powder / liquid ratio. In addition, injection of the material directly through the capsule leads to increased ionomer resistance [9]. In this work both materials were used in the encapsulated form. Porosities, which are intrinsic to glass ionomers [12], were minimized with the injection of materials, which also benefited both materials tested [9].

Another aspect of extreme importance in the restorative technique is the time that must be waited until the initial hardening of the material to start finishing and expose GIC in contact with water [13]. Works on the ART technique do not mention the maintenance time $[14,15]$ or when it is mentioned, it is below the setting time mentioned on the manufacturer's instructions $[8,16]$. It is also of utmost relevance the matrix removal to guarantee the stabilization of the GIC setting reaction and the bonding of the material to the dental structure [13]. In this study we waited 6 minutes for both materials.

Study with Fourier transform infrared (FTIR) and Raman spectroscopy has shown that the setting time to achieve bond stability of GIC with dentin was longer for the high-viscosity GIC (38 $\pm 7 \mathrm{~min}$ ) than for the sample with $29 \%$ of GIC (28 $\pm 4 \mathrm{~min})$ [13]. In this work the matrix was maintained for both materials for 6 minutes and removed carefully. Any excess material was removed with movements from restoration to tooth structure, avoiding any movement that could disrupt the restoration from the cavity walls.

In this study one of the materials (CR) was used without prior cavity conditioning, according to the manufacturer's instructions, while for the EF the cavities were previously conditioned with polyacrylic acid. There was no statistically significant difference between the materials tested, what clinically represents an advantage for CR, as it is one less step in the restorative technique. Clinicians should consider all the characteristics to choose the best material to use in each specific case.

It was observed that the tip of the capsule of the ionomer ChemFil Rock is very wide and may hamper access to the more conservative cavities, and the tip of the capsule of the Equia Fil is of adequate dimensions.

Data from this study confirmed the observations of Barata et al. [9], who observed an increase in compressive strength of restorations in premolar teeth prepared with rotary instruments and with proximal retention compared to proximal restorations without retention. The present study was performed on molar teeth, with preparations made by ART technique. Both studies need to be validated with randomized clinical trials.

It is important to note that there is a significant difference in the fractures that occur in the laboratory tests of those that occur clinically [17]. In the laboratory test the applied force is controlled and its application is continuous, whereas in the mouth there is a variation of magnitude and speed of application of the forces, but the results of laboratory studies constitute an initial source of information for the clinicians.

In the mouth it is practically impossible to standardize the dimensions of the cavities, the access to the tooth to be restored and the powder / liquid ratio that are crucial factors for the performance of the restoration. Laboratory tests allow the standardization and isolation of variables that cannot be individualized in the clinic [9]. 


\section{CONCLUSION}

The performance of retentive grooves made with hand instruments significantly improved fracture resistance of Class II GIC ART restorations for booth encapsulated materials tested.

\section{REFERENCES}

1. Sidhu SK, Nicholson JW. A Review of Glass-Ionomer Cements for Clinical Dentistry. J Funct Biomater. 2016 Jun 28;7(3). pii: E16. doi: 10.3390/jfb7030016.

2. Guggenberger R, May R, Stefan KP. New trends in glass-ionomer chemistry. Biomaterials. 1998 Mar;19(6):479-83.

3. Frencken JE, Leal SC, Navarro MF. Twenty-five-year atraumatic restorative treatment (ART) approach: a comprehensive overview. Clin Oral Investig. 2012 0ct;16(5):1337-46. doi: 10.1007/s00784-012-0783-4. Epub 2012 Jul 24

4. van 't Hof MA, Frencken JE, van Palenstein Helderman WH, Holmgren CJ. The Atraumatic Restorative Treatment (ART) approach for managing dental caries: a meta-analysis. Int Dent J. 2006 Dec;56(6):345-51.

5. de Amorim RG, Leal SC, Frencken JE. Survival of atraumatic restorative treatment (ART) sealants and restorations: a metaanalysis. Clin Oral Investig. 2012 Apr;16(2):429-41. doi: 10.1007/s00784011-0513-3. Epub 2011 Jan 28.

6. Zoergiebel J, llie N. Evaluation of a conventional glass ionomer cement with new zinc formulation: effect of coating, aging and storage agents. Clin Oral Investig. 2013 Mar;17(2):619-26. doi: 10.1007/s00784-0120733-1. Epub 2012 May 2.

7. Bonifácio CC, Werner A, Kleverlaan CJ. Coating glass-ionomer cements with a nanofillled resin. Acta Odontol Scand. 2012 Dec;70(6):471-7. doi: 10.3109/00016357.2011.639307. Epub 2011 Dec 12.
8. Molina GF, Cabral RJ, Mazzola I, Lascano LB, Frencken JE. Mechanical performance of encapsulated restorative glass-ionomer cements for use with Atraumatic Restorative Treatment (ART). J Appl Oral Sci. 2013;21(3):243-9. doi: 10.1590/1679-775720130129.

9. Esteves Barata TJ, Bresciani E, Cestari Fagundes T, Gigo Cefaly DF Pereira Lauris JR, Lima Navarro MF. Fracture resistance of Class II glass-ionomer cement restorations. Am J Dent. 2008 Jun;21(3):163-7.

10. Humel MMC, Oliveira MT, Cavalli V, Giannini M. Effect of storage and disinfection methods of extracted bovine teeth on bond strength to dentin. Braz J Oral Sci. 2007;6(22):1402-6.

11. ANSI/ADA specification no. 66 for dental glass ionomer cements. Council on Dental Materials, Instruments, and Equipment. J Am Dent Assoc. 1989 Jul;119(1):205.

12. Nomoto R, Mccabe JF. Effect of mixing methods on the compressive strength of glass ionomer cements. J Dent. 2001 Mar;29(3):205-10.

13. Yamakami SA, Ubaldini ALM, Sato F, Medina Neto A, Pascotto RC, Baesso ML. Study of the chemical interaction between a highviscosity glass ionomer cement and dentin. J Appl Oral Sci. $2018 \mathrm{Jul}$ 16;26:e20170384. doi: 10.1590/1678-7757-2017-0384.

14. Ercan E, Dulgergil T, Soyman M, Dalli M, Yildirim I. A field-trial of two restorative materials used with atraumatic restorative treatment in rural Turkey: 24-month results. J Appl Oral Sci. 2009 JulAug;17(4):307-14.

15. Bonifácio CC, Hesse D, de Oliveira Rocha R, Bonecker M, Raggio DP, van Amerogen WE. Survival rate of appoximal- ART restorations using a two-layer technique for glass ionomer insertion. Clin Oral Investig. 2013 Sep;17(7):1745-50. doi: 10.1007/s00784-012-0859-1. Epub 2012 Oct 11.

16. Koenraads H, Van Der Kroon G, Frencken JE. Compressive strength of two newly developed glass-ionomer materials for use with the Atraumatic Restorative Treatment (ART) approach in class II cavities. Dent Mater. 2009 Apr;25(4):551-6. doi: 10.1016/j.dental.2008.12.008. Epub 2009 Feb 10.

17. Jagadish $\mathrm{S}$, Yogesh BG. Fracture resistance of teeth with Class 2 silver amalgam, posterior composite, and glass cermet restorations. Oper Dent. 1990 Mar-Apr;15(2):42-7.

\section{Maria Fidela de Lima Navarro}

\section{(Corresponding address)}

Department of Dental Materials, Endodontics and Operative Dentistry

Bauru School of Dentistry, University of São Paulo,

Al. Octávio Pinheiro Brisola, 9-75, CEP 17012-901, Bauru/São Paulo, Brazil

Date submitted: 2018 0ct 24

mflnavar@usp.br 